\title{
'Optimal' Retaliation in the WTO - a commentary on the Upland Cotton Arbitration
}

\author{
GENE M. GROSSMAN * \\ Princeton University \\ ALAN O. SYKES* * \\ Stanford University
}

\begin{abstract}
The Upland Cotton case raises a range of interesting issues regarding the rationale for retaliation in the WTO system and the proper approach to its calibration. These include: Should the approach to retaliation differ in cases involving prohibited or actionable subsidies? When should cross-retaliation be allowed? Should retaliation be based only on the harm to the complaining nation, or to other nations as well? And, most importantly, what economic content can be given to the standard of countermeasures 'equivalent to the level of nullification or impairment'? We address these and other issues from both a legal and economic perspective, with particular attention to the question of what level of retaliation will restore the lost welfare of the complaining nation.
\end{abstract}

The United States is a leading producer and exporter of cotton. Its market share in world cotton trade has averaged $37 \%$ since the year 2000, and some $70 \%$ of US production on average has been exported. ${ }^{1}$ The US cotton industry has also long been the beneficiary of various forms of government support, averaging some $\$ 3.55$ billion per year since 2000 , as compared with average annual cotton output in the United States of $\$ 4.26$ billion. $^{2}$ These statistics alone suggest that US government programs for cotton production have had a sizeable impact on the competitive position of US cotton growers.

In 2002, Brazil requested consultations with the United States regarding various US government programs benefiting producers of upland cotton. A Panel was constituted in 2003 to adjudicate claims that US programs constituted actionable subsidies under Part III of the Subsidies and Countervailng Measures (SCM) Agreement, prohibited subsidies under Part II of the SCM Agreement, illegal export subsidies under the Agreement on Agriculture, and actionable subsidies

\footnotetext{
* Email: grossman@princeton.edu

**Email: asykes@stanford.edu

1 Schnepf (2010:6).

2 Ibid.: 7. Schnepf uses data from the USDA Farm Service Agency, Budget Division, available at http://www.fsa.usda.gov/FSA/webapp?area=about\&subject=landing\&topic=bap-bu-uc.
} 
under Article XVI of GATT. The Panel ruled that a variety of US programs were inconsistent with the Agreement on Agriculture, and thus not exempt from actions under pertinent provisions of the SCM Agreement and GATT Article XVI. ${ }^{3}$ On appeal, the Appellate Body confirmed that certain US programs were actionable subsidies that had caused serious prejudice to Brazil, and that other programs were either prohibited export subsidies or prohibited subsidies contingent on the use of domestic over imported goods. ${ }^{4}$

The United States subsequently introduced various modifications to its programs affecting the production of upland cotton, but some of the problematic provisions remained little changed. Brazil thus initiated a compliance proceeding pursuant to Dispute Settlement Understanding (DSU) Article 21.5. The compliance Panel ruled in 2007 that certain marketing loan and countercyclical payments by the United States were being provided under the same conditions and criteria as those found to cause serious prejudice by the original Panel, and that the United States had failed to bring these measures into compliance. Likewise, the Panel ruled that the United States continued to provide certain export credit guarantees that amounted to a circumvention of the US commitments under the Agreement on Agriculture and thus to prohibited export subsidies under the SCM Agreement. ${ }^{5}$ The United States again appealed, and although the Appellate Body modified several findings of the Panel, it nevertheless upheld the Panel's key results. ${ }^{6}$

In the interim, Brazil requested authorization to retaliate against the United States following the expiration in 2005 of the 'reasonable periods of time' for the United States to bring its policies into compliance. ${ }^{7}$ The United States objected to the proposed retaliation and the matter was referred to arbitration under DSU Article 22.6. The arbitration was suspended during the compliance litigation, but in 2008 Brazil requested that it be resumed.

Our focus in this paper is on the two arbitration decisions regarding the proposed level of retaliation by Brazil, one pertaining to the prohibited subsidies, ${ }^{8}$ and the other pertaining to the actionable subsidies. ${ }^{9}$ Both decisions calculated an allowable level of retaliation in goods sectors based on the magnitude of US subsidies during prior years, and offer a formula for retaliation based on future subsidy levels. They further provide authority for Brazil to suspend concessions under

3 Panel Report, United States - Subsidies on Upland Cotton, WT/DS267/R, 8 September 2004.

4 Appellate Body Report, United States - Subsidies on Upland Cotton, WT/DS267/AB/R, 3 March 2005.

5 Panel Report, United States - Subsidies on Upland Cotton, Recourse to Article 21.5 of the DSU by Brazil, WT/DS267/RW, 20 December 2007.

6 Appellate Body Report, United States - Subsidies on Upland Cotton, Recourse to Article 21.5 of the DSU by Brazil, WT/DS267/AB/RW, 2 June 2008.

7 The 'reasonable period' expired earlier for the prohibited subsidies than for the actionable subsidies. 8 WT/DS267/ARB/1, 31 August 2009 (hereafter Prohibited Subs. Arb.).

9 WT/DS267/ARB/2, 31 August 2009 (hereafter Actionable Subs. Arb.). 
TRIPs or GATS in the event that the total allowable retaliation in goods sectors exceeds a certain threshold.

The analysis of the Arbitrator in each decision is complex and raises a wide range of issues. We cannot hope to address all of them in this brief commentary, and will focus on the issues that seem to us to be the most central for the remedial system, and to have the broadest implications for other possible disputes.

Sections 1 (prohibited subsidies), 2 (actionable subsidies), and 3 (crossretaliation) set out the core legal issues that we wish to address, and the decision of the Arbitrator with respect to each set of issues. They also contain our own legal commentary on the issues, a commentary that is brief due to the lack of much useful guidance in the treaty text or from any well-established WTO practice. Section 4 contains our economic analysis.

\section{Key issues and legal analysis - prohibited subsidies}

A number of US programs were found to constitute prohibited subsidies in the original Upland Cotton litigation. These included payments under a program known as 'Step 2', found to constitute import substitution subsidies, along with export credit guarantees under programs known as GSM 102, GSM 103, and SGCP, which were found to constitute export subsidies. The 'reasonable time' for the United States to bring these programs into compliance with its obligations expired on 1 July 2005. The United States stopped accepting applications for export guarantees under GSM 103 on 30 June 2005, and announced a new fee structure for GSM 102 and SGCP at the same time. In October 2005, it announced an end to the SGCP program altogether. The Step 2 program continued until it was repealed, effective 1 August 2006. After that time, only GSM 102 remained in effect, as modified in June 2005. Brazil argued before the compliance Panel that the new fee structure for GSM 102 did not solve the problem of subsidization, and the Panel and Appellate Body agreed.

This chronology raised two core issues regarding retaliation. First, could Brazil retaliate for the now repealed programs that had continued after 1 July 2005 ? Second, what was the proper measure of retaliation with respect to the ongoing GSM 102 program?

\section{Expired programs}

In its request to the Dispute Settlement Body, Brazil sought authorization for 'one-time' countermeasures in the amount of US\$350 million, which was based on the Step 2 payments made between 1 July 2005 and 30 June 2006 before the program was repealed. Brazil bolstered its argument for countermeasures against this expired program by arguing that the 2008 US Farm Bill enacted new programs benefiting upland-cotton producers that Brazil believed to constitute illegal subsidies. Those new programs had not been the subject of a WTO complaint by Brazil, however, and had not been addressed by the compliance Panel. Likewise, 
Brazil did not ask the Arbitrator to adjudicate the issue of their WTO consistency, but simply urged the Arbitrator to 'take into account' the existence of these new programs. ${ }^{10}$

The Arbitrator noted the repeal of Step 2 and the fact that the compliance Panel made no findings regarding the program because of its repeal. It then noted various textual provisions of the DSU to the effect that countermeasures were an extraordinary remedy to be used on a temporary basis following the 'reasonable period' for compliance. Most prominent in this respect is DSU Article 22.8, which provides:

The suspension of concessions or other obligations shall be temporary and shall only be applied until such time as the measure found to be inconsistent with a covered agreement has been removed, or the Member that must implement recommendations or rulings provides a solution to the nullification or impairment of benefits, or a mutually satisfactory solution is reached.

Brazil argued that this provision relates only to the duration of countermeasures and not to their initial authorization, but the Arbitrator had little difficulty dismissing this distinction, holding that countermeasures are impermissible after a WTO-inconsistent measure has been repealed, absent a finding that the measure has been replaced by a new measure that amounts to substantive noncompliance. ${ }^{11}$

As a legal matter, we have no quarrel with the analysis of the Arbitrator. The treaty text is clear that countermeasures are limited to a window of time following the reasonable period for compliance, and delimited by the date of compliance or one of the other enumerated events in DSU Article 22.8. WTO practice has been consistent in this regard. We also see no legal basis for departing from these principles simply because a complaining nation alleges that some new violation exists that has not yet been adjudicated by an original Panel or examined as part of a compliance Panel proceeding.

Of course, the effect of these principles is to insulate a violator from retaliation for violations that it cures within a 'reasonable period of time', perhaps supplemented by a further period of compliance litigation. At first blush, such a system might appear to create an 'engraved invitation' for temporary cheating in the system, and indeed has come to be known colloquially as the 'three-year free pass ${ }^{12}$ It is thus open to question from an economic standpoint, an issue that we address in Section 4.

10 See Prohibited Subs. Arb., para. 3.93.

11 See ibid., para. 3.95.

12 One potential abuse has been addressed by the Appellate Body. If a nation repeals a program that violates WTO rules, and replaces it with another that has much the same effect, it cannot then argue that retaliation is impermissible because the new program has not been the subject of an adjudication. Rather, a compliance Panel may examine the new program for 'substantive compliance' with the original ruling, and retaliation may be authorized if the new program fails this test. The difference in Upland Cotton is that the new US Farm Bill programs were enacted two years after the repeal of Step 2, and had not been examined by the compliance Panel. 


\section{Continuing programs - the retaliation metric}

Of the programs originally found to constitute prohibited subsidies, only GSM 102 , an export credit guarantee program, remained in effect at the time of the Article 22.6 arbitration. The compliance Panel had ruled earlier that the modifications introduced in 2005 were inadequate to put the program into compliance, and that it continued to confer prohibited export subsidies. The amount of retaliation requested by Brazil was based on the value of the interest-rate subsidy under the program, plus Brazil's estimate of the marginal additional exports by creditworthy borrowers ('marginal additionality'), plus the value of all exports by noncreditworthy borrowers on a number of unscheduled products, plus rice, poultry, and pork ('full additionality'). Brazil calculated these amounts as $\$ 237.4$ million, $\$ 62.3$ million, and $\$ 855$ million, respectively. ${ }^{13}$

The United States argued in response that Brazil's proposed method of calculation was flawed. It noted that the export credit guarantee program was found to constitute a subsidy with reference to illustrative item (j) in Annex I of the SCM Agreement, which provides that export credit programs constitute a subsidy when the fees for participation do not cover the costs of the program. ${ }^{14}$ Accordingly, the United States argued, the appropriate measure of the subsidy was the net cost of the program to the US government, an amount that it urged should cap the amount of retaliation. The United States did not specify this amount but offered to calculate it. The United States further argued that 'a reduction should be made' because 'Brazil may only take such countermeasures with respect to the impact of the alleged subsidy on itself. If Brazil were permitted to take countermeasures for the entire amount of the subsidy, it would create a conflict for other Members who may have an interest in the GSM 102 program. ${ }^{15}$

One core issue here, therefore, concerns the proper metric for calibrating retaliation. Is it the value of the subsidy, as had been the case in some prior prohibited-subsidies cases? Is it the impact of the subsidy on the volume of trade? Or is it something else? A second core issue concerns the retaliation rights of an individual country in relation to a subsidy program that affects the trade of many countries - can the complaining nation retaliate based on the global effect of the subsidy, or only the effects on itself? Finally, once these questions are answered, it remains to calculate the amount of retaliation under the chosen standard, a potentially complex calculation that itself raises a variety of issues.

13 Prohibited Subs. Arb., para. 4.110.

14 Item (j) states: 'The provision by governments (or special institutions controlled by governments) of export credit guarantee or insurance programmes, of insurance or guarantee programmes against increases in the cost of exported products or of exchange risk programmes, at premium rates which are inadequate to cover the long-term operating costs and losses of the programmes.'

15 Prohibited Subs. Arb., para. 4.114. 


\section{The decision of the Arbitrator}

The usual standard for WTO countermeasures is found in DSU Article 22.4: 'The level of the suspension of concessions or other obligations authorized by the DSB shall be equivalent to the level of the nullification or impairment.' This standard is understood to refer to the harm done to nations adversely affected by a violation - the 'nullification or impairment' of the benefits to which they are entitled under the WTO bargain. Accordingly, in the typical case governed by DSU Article 22.4, the focus is on the trade impact of the violation, and the allowed retaliation is to be 'equivalent'. Thus, an Arbitrator will commonly calculate the value of lost trade due to the violation, and then authorize retaliation in an equal amount - complaining nations, for example, may impose prohibitive tariffs on imports from the violator nation to a degree sufficient to choke off exports from the violator in an amount equal to the value lost because of the violation.

In prohibited-subsidies cases, however, the SCM Agreement introduces another wrinkle. Article 4.10 states: 'In the event the recommendation of the DSB is not followed within the time-period specified by the panel, which shall commence from the date of adoption of the panel's report or the Appellate Body's report, the DSB shall grant authorization to the complaining Member to take appropriate countermeasures...' A footnote to the word 'appropriate' further states: 'This expression is not meant to allow countermeasures that are disproportionate in light of the fact that the subsidies dealt with under these provisions are prohibited.' The 'appropriate countermeasures' standard was interpreted in prior prohibitedsubsidies cases-Brazil-Aircraft ${ }^{16}$ Canada-Aircraft ${ }^{17}$ and United States-Foreign Sales Corporations $(F S C)^{18}$ - to authorize countermeasures in an amount equal to the value of this subsidy. And, in the FSC decision, the complainant (Europe) was permitted to retaliate at a level equal to the full value of the subsidy. No reduction was made for the fact that other nations had also suffered adverse effects due to the subsidy.

The US position on retaliation, which focused on the value of the subsidy, followed directly from these earlier cases. Of course, the United States was also seeking to avoid the FSC outcome, by insisting that Brazil's retaliatory rights should be reduced in some fashion to reflect the fact that other nations were also affected by the subsidy and might in principle seek their own retaliation rights in the future.

16 Brazil - Export Financing Programme for Aircraft, Recourse to Arbitration by Brazil under Article 22.6 of the DSU and Article 4.11 of the SCM Agreement, WT/DS46/ARB, 28 August 2000.

17 Canada - Export Credits and Loan Guarantees for Regional Aircraft, Recourse to Arbitration by Canada under Article 22.6 of the DSU and Article 4.11 of the SCM Agreement, WT/DS222/ARB, 17 February 2003.

18 United States - Tax Treatment for 'Foreign Sales Corporations', Recourse to Arbitration by the United States under Article 22.6 of the DSU and Article 4.11 of the SCM Agreement, WT/DS108/ARB, 30 August 2002. 
Brazil's position, by contrast, sought an entirely new measure as the standard it wished to sum the value of the subsidy with the value of worldwide exports stimulated by the subsidy. It also wished to avoid any reduction in retaliation rights based on the fact that the subsidy had adverse effects on other countries besides Brazil.

The Arbitrator rejected both proposals. It agreed with Brazil and with prior case law that the 'appropriate countermeasures' standard was looser than the 'equivalence' standard of DSU Article 22.4. Yet, emphasizing the footnote that cautions against 'disproportionate' countermeasures, the Arbitrator concluded:

[C]ountermeasures, in order to be 'appropriate', should bear some relationship to the extent to which the complaining Member has suffered from the tradedistorting impact of the illegal subsidy. Countermeasures are in essence traderestrictive measures to be taken in response to a Member's application of a trade-distorting measure that has been determined to nullify or impair the benefits accruing to another Member. Countermeasures that would ensure a relationship of proportionality between the extent to which the trade opportunities of the Member applying the countermeasures has been affected and the extent to which the trade opportunities of the violating Member will in turn be adversely affected would notionally restore the balance of rights and obligations arising from the covered agreements that has been upset between the parties. This would ensure a proper relationship between the level of the countermeasures and the circumstances out of which the dispute arises. ${ }^{19}$

The Arbitrator further noted the standard for countermeasures in 'actionable subsidies' cases under SCMs Article 7.9, which contemplates countermeasures 'commensurate' with the adverse effects of the subsidy. It viewed the 'appropriate' standard of SCMs Article 4.10 as a 'more flexible' standard, and concluded that the adverse effects of the subsidy on the complaining member in effect provide a floor for the level of retaliation. ${ }^{20}$ Finally, while acknowledging that an objective of all WTO countermeasures is to 'induce compliance', the Arbitrator rejected the notion that this objective delinked the level of countermeasures from the adverse effects of the violation. ${ }^{21}$

For these reasons, the Arbitrator rejected the notion put forward by the United States that the value of the subsidy was necessarily the proper standard in prohibited-subsidies cases. It also rejected the US claim that the proper way to value the subsidy should focus on the net cost to the government, observing that the benefit to the recipient of subsidies was the typical standard for valuing subsidies under WTO law. The proper valuation must thus ask what borrowers would have had to pay for credit in the private market. 
The Arbitrator also rejected the Brazilian proposal to base retaliation on the total value of the subsidy plus the increase in worldwide US exports due to the subsidy. This amount was not properly linked to the adverse effects suffered by Brazil.

But the Arbitrator did accept Brazil's notion that the harm from the subsidy included a lost-volume-of-trade component, and a price-suppression component. It found that the additional export sales stimulated by the subsidy were an approximation of the lost quantity of sales by all other producers, recognizing that it might overstate that amount. It also argued that the value of the subsidy (measured against market interest rates) was an approximation to the price-suppression effect suffered by all non-US producers. These amounts could thus be summed to approximate the adverse effects on non-US producers. What remained was to adjust the calculation to capture the harm to Brazil in particular. To estimate the adverse effects on Brazil in its export markets, the Arbitrator suggested that these total price and volume effects in those markets should be multiplied by Brazil's market share of the products in question. The total price and volume effects in Brazil's home market would then be added to obtain the total amount of permissible retaliation. ${ }^{22}$

In the end, therefore, the Arbitrator adopted a variant of Brazil's original proposal. It suggested that Brazil's calculation of the value of the subsidy approximated the lost revenue abroad, while the exports stimulated by the subsidy approximated the lost volume of sales abroad. The Arbitrator recognized that these estimates were crude and might overstate the harm, but argued that they were nevertheless acceptable under the 'appropriateness' standard of SCMs Article 4.10. The key departure from Brazil's original proposal was the requirement that the harm be apportioned to the harm suffered by Brazil, which was done by adjusting it downward using Brazil's market share in its export markets.

Much of the remainder of the decision focuses on the details of the calculations pursuant to this standard. The Arbitrator undertook to value the subsidy based on the spread between the subsidized export credit price and the market price of credit, taking account of the creditworthiness of borrowers. It also sought to value the additional quantity of exports to noncreditworthy and creditworthy borrowers. Ultimately, the amounts calculated for fiscal year 2006 for these three components were US\$25.3 million, $\$ 80.8$ million, and $\$ 41.3$ million, respectively, for a total figure of $\$ 147.4$ million, in contrast to Brazil's original proposal in the amount of $\$ 1.12$ billion. ${ }^{23}$ The Arbitrator's calculation also provides a formula for retaliation in future years when US subsidy expenditures may increase or decrease.

\section{Legal analysis}

The textual standard for countermeasures under WTO law is at best vague. The 'equivalence' standard under DSU Article 22.4 does seem to require that 
countermeasures bear relation to the harm suffered by aggrieved parties, but offers little guidance as to how this arm should be measured. The looser 'appropriateness' standard of SCMs Article 4.10 provides even less clarity.

Neither can one rely much on established practice. Formal sanctions under GATT were nonexistent save for one case in the 1950s (in which they were authorized but not used). The brief period of WTO practice since 1995, involving a rather small number of cases, divides into a focus on lost trade volume in cases under DSU Article 22.4, and a focus on the value of the subsidy in prior cases under SCMs Article 4.10. The Arbitrator in Upland Cotton obviously departed from the value of the subsidy as the measure of retaliation, but we cannot condemn this departure as a legal matter simply because of its inconsistency with three prior unappealed (and unappealable) arbitrations involving prohibited subsidies. The 'appropriateness' standard confers significant discretion on a process that has no appellate oversight, and we have no basis for suggesting that the Arbitrator here abused its discretion.

Likewise, the Arbitrator's determination that retaliation should be apportioned based on the amount of harm suffered by Brazil was a departure from the outcome in the FSC case. But the FSC arbitration has been criticized on the grounds that if complaining nations could each retaliate based on the effect of the subsidy on all nations, cumulative retaliation might ultimately prove 'disproportionate' (see, e.g., Howse and Neven, 2005). This critique is not without logic, and the decision of the Arbitrator in Upland Cotton to apportion retaliation rights based on market share seems a reasonable response to this concern.

In short, although Upland Cotton departs from prior 'precedent' ${ }^{24}$ in significant ways, we cannot say that it is at odds with any element of the treaty text or any well-established practice. The issues here are much more issues of policy and economics, which we reserve for Section 4.

\section{Key issues and legal analysis - actionable subsidies}

The programs at issue as actionable subsidies were nonrecourse marketing loans (ML) and counter-cyclical payments (CCP) that resulted in payments to farmers when prices fell below a target level. Both the original Panel and the compliance Panel determined that these programs were subsidies because they provide net payments from the government, and that they had caused 'serious prejudice' to Brazil in the form of price suppression in violation of SCMs Article 6.

The United States argued that these programs, part of the 2002 Farm Bill, had expired at the time of the arbitration. The Arbitrator responded that the compliance Panel had ruled against the United States when these programs were examined, and that essentially the same programs had been reenacted in the 
2008 Farm Bill. Accordingly, it rejected the suggestion that retaliation was impermissible because of the expiry of the 2002 Farm Bill. ${ }^{25}$

The standard in the SCM Agreement for countermeasures against actionable subsidies is found in Article 7.9: '[T]he DSB shall grant authorization to the complaining Member to take countermeasures, commensurate with the degree and nature of the adverse effects determined to exist...' This language is similar to that in DSU Article 22.4, which refers to countermeasures 'equivalent to the level of nullification or impairment'. The Arbitrator suggested that the two standards are not identical, and that the requisite linkage to the harm suffered by the complaining nation is less strict under SCMs Article 7, but that nevertheless Article 7 links countermeasures to the harm suffered: "[T]he term "commensurate" connotes a less precise degree of equivalence than exact numerical correspondence. Nonetheless, the term "commensurate" does indicate, in our view, a relationship of correspondence and proportionality between the two elements. ${ }^{26}$

To Brazil's suggestion that stiffer countermeasures ought be allowed for the purpose of 'inducing compliance', the Arbitrator responded: '[T] he terms of Article 7.9 of the SCM Agreement, which refer exclusively to the "degree and nature of the adverse effects determined to exist", do not suggest that there would be any basis for increasing their level, in a subjective sense, to specifically take into account a superadded objective of inducing compliance. We are not empowered to " adjust" the level of countermeasures beyond what these terms allow'. ${ }^{27}$ Likewise, as it had ruled with respect to the prohibited subsidies, the Arbitrator held that the 'adverse effects' relevant to the calibration of countermeasures are the adverse effects on Brazil, not the entirety of the adverse effects on non-US producers. ${ }^{28}$

Finally, recall that the basis for the finding of 'serious prejudice' under SCMs Article 6 was 'significant price suppression'. The United States argued from this language that only the amount of price suppression above the 'significance' threshold should be considered for retaliation. The Arbitrator rejected this suggestion, concluding that:

[t] he threshold of 'significance' is set in order to ascertain whether the price suppression at issue is sufficiently 'important, notable or consequential', as the original panel put it, to fall within the scope of Article 6.3(c) and form the basis of a finding of 'serious prejudice' under Article 6 of the SCM Agreement. Once it is determined that the price suppression is significant, and therefore that it is within the scope of the provision, then it is the entirety of that existing 'significant price suppression' that is the basis for the determination of 'serious prejudice'. To adjust the level of price suppression downwards, for the purposes of estimating the level of countermeasures that Brazil is entitled to, would mean that we would not in fact take into account the entirety of the situation that has given rise 
to the findings, namely the fact that a certain degree of price suppression exists on the world cotton market, that has been found to be 'significant' ${ }^{29}$

After disposing of a few other minor issues that we omit here, the Arbitrator turned to the task of calculating the appropriate countermeasures. The calculation relied on a simulation model of the world cotton market that sought to estimate the effect on world market prices and non-US production of the subsidy programs at issue. The conceptual approach was summarized by the Arbitrator as follows:

Brazil's calculation of adverse effects from US marketing loans and countercyclical payments can be graphically represented by Figure 1. It represents the supply curve of a cotton producing country in the rest of the world. With US subsidies in place, the world price is at OP and quantity produced in the country at OQ. Without the US subsidies, the world price would be at the higher level OP' and cotton producers in the country would have responded by producing more cotton, represented here by OQ'.

Figure 1. Adverse Effects on Producers in the Rest of the World

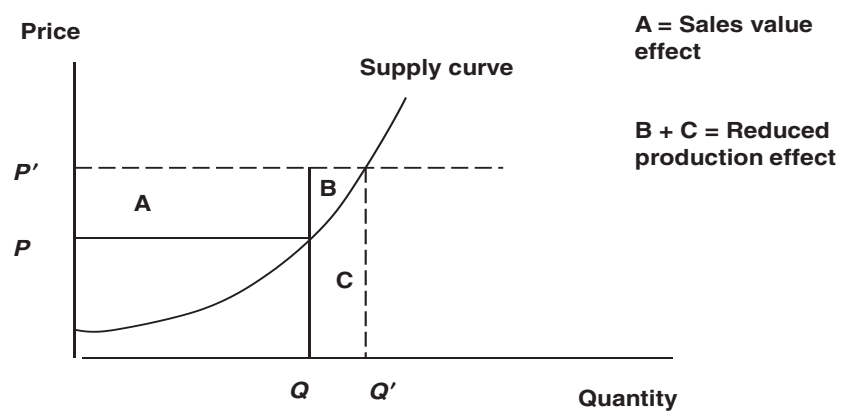

The area $\mathbf{A}$ in Figure 1 is what Brazil terms the 'sales value effect' while the sum of the areas $\mathbf{B}$ and $\mathbf{C}$ is what it terms the 'reduced production effects'. The Arbitrator notes that the United States has not disputed Brazil's decomposition of the adverse effects from the actionable subsidies into this sales value and reduced production effects. An alternative way of characterizing these effects can be provided using standard economic concepts. The sales value effect is the increase in producer surplus that farmers in the rest of the world would have received based on their current output of cotton had world prices been at the counterfactual (no subsidies) level. The reduced production effects are made up of two parts: the producer surplus from the additional production $Q Q^{\prime}$ (area B) and the opportunity cost of the resources needed to produce the additional cotton (area C). The Arbitrator notes that if one were only interested in measuring how US cotton subsidies have reduced producer welfare in the rest of the world, then this would be represented by the loss in producer surplus (sum of areas A and $\mathbf{B}$ ). This is because those resources used to produce $Q Q^{\prime}$ of cotton would have

29 Ibid., para. 4.104-4.105. 
found employment elsewhere and consequently, there would have been no loss associated with those resources to the rest of the world. However, the Arbitrator understands that adverse effects may have a wider meaning than producer surplus and that Brazil's economic analysis of adverse effects is consistent with the language of Article 6.3(c) of the SCM Agreement, particularly in its reference to 'lost sales'. 30

Having endorsed the conceptual approach of Brazil (with the proviso that retaliation should be limited to the harm suffered by Brazil), the Arbitrator proceeded to examine a number of detailed issues that bear on the resulting numerical calculation. We will omit discussion of most of these issues, but note one of fairly broad significance. To calibrate the simulation model, elasticity estimates are required, and the question arises whether these should be based on long-run or short-run elasticity estimates. Long-run elasticities, of course, are higher as they assume free entry and exit of capital in response to price changes. The use of long-run supply elasticities for rest-of-world cotton producers results in a calculation more favorable to the United States, because the larger production response by these supplies mitigates the effect of any change in US output on the world price.

Accordingly, the United States argued for long-run elasticities for rest-of-world suppliers, while Brazil argued for short-run elasticities. The Arbitrator noted that the United States had the burden of proving that Brazil's approach was inappropriate, and then ruled for Brazil:

Brazil has established a plausible case that it will take time for consumers and producers to fully adjust to the removal of marketing loans and countercyclical payments. As we have noted in our analysis, this means that producers in the rest of the world would continue to experience the adverse effects of the subsidies even after they have been removed. Since the calculated countermeasures must be 'commensurate with the degree and nature of the adverse effects determined to exist', the Arbitrator believes that the economic modelling must account for these rigidities. This makes a short-run analysis, and the use of short-run elasticities, not inappropriate for the economic modelling. ${ }^{31}$

After sorting through these and a variety of other issues pertaining to the calculation, the Arbitrator recalculated the price and output effects of the US subsidies using data from the reference period. It concluded that the total adverse effect on non-US producers was approximately US\$3 billion. Applying Brazil's market share of roughly $5 \%$, Brazil's retaliation rights were estimated at roughly $\$ 150$ million. $^{32}$ Combined with its rights relating to prohibited subsidies as discussed earlier, Brazil's total retaliation rights were then set at roughly $\$ 300$ million.

30 Ibid., paras. 4.128-4.129.

31 Ibid., para. 4.147.

32 Ibid., paras. 4.194-4.195. 


\section{Legal analysis}

We endorse the Arbitrator's unwillingness to allow the United States to avoid retaliation based on the formalist argument that the 2002 Farm Bill had expired, given that the essential programs had been renewed in the 2008 Farm Bill. A contrary position would allow violators to escape all sanction by 'repealing' offending policies and then reenacting them under another name, a result that would render countermeasures inutile.

Regarding the magnitude of countermeasures, the standards in the WTO are loose and provide only limited guidance. The standard in SCMs Article 7.9 is no different - 'commensurate with the adverse effects' simply requires some degree of correspondence between the countermeasures and the adverse effects, but the precise correspondence is unclear and the concept of 'adverse effects' is nowhere defined. The Arbitrator's interpretation of the standard seems broadly reasonable, and we see no basis in the treaty text or in settled practice for any serious quarrel. The decision to limit countermeasures based on the harm done to Brazil, rather than to allow Brazil to retaliate based on the global effects of the violation, is inconsistent with the approach in the FSC arbitration as we noted earlier, but seems sensible in light of the critique of the FSC decision and the resulting potential for retaliation out of proportion to the harm done to trading partners. Likewise, the decision to allow retaliation based on the totality of price suppression, and not just the amount by which it exceeds a 'significance' threshold, seems reasonable and consistent with the principle of countermeasures 'commensurate with the adverse effects'.

We might quibble somewhat with the Arbitrator's willingness to allow retaliation based on the entire lost production effect in Figure 1 above. As the Arbitrator acknowledges, areas $\mathrm{A}$ and $\mathrm{B}$ capture the lost surplus to firms and workers due to the violation, whereas area $\mathrm{C}$ reflects a savings of resources that are diverted to other productive uses. It is difficult to understand conceptually how a shift of resources into other productive uses is properly deemed an 'adverse effect' of the subsidy, although we recognize that the concept of 'adverse effects' is not necessarily limited to lost producer surplus. We will have more to say about this issue in Section 4, but simply remark at this point that the Arbitrator offers no theoretical basis for treating area $\mathrm{C}$ as an 'adverse effect'.

Finally, the debate over short-run versus long-run elasticities seems to us to come down to the question of which parameters do the best job of capturing the 'adverse effects' of a subsidy program. Without a clear theory as to the proper conceptual measure of 'adverse effects', it is difficult to say what parameters should be used to estimate them. Again, we will have more to say about these issues in Section 4.

\section{Key issues and legal analysis - cross-retaliation}

Aside from questions about the permissible magnitude of retaliation, Upland Cotton raises important questions about the appropriate subject of retaliation. 
In particular, as in EC Bananas-III ${ }^{33}$ and United States-Gambling, ${ }^{34}$ Brazil sought authority to use its retaliation rights to suspend concession under the TRIPs. The United States objected, arguing that the conditions for cross-retaliation set forth in the DSU were not met.

\section{The decision of the Arbitrator}

An initial question was whether countermeasures governed by SCMs Article 4.10 (or 7.9 in the case of the actionable subsidies) are also required to conform to pertinent provisions of the DSU, in particular, Article 22.3, which provides:

In considering what concessions or other obligations to suspend, the complaining party shall apply the following principles and procedures:

(a) the general principle is that the complaining party should first seek to suspend concessions or other obligations with respect to the same sector(s) as that in which the panel or Appellate Body has found a violation or other nullification or impairment;

(b) if that party considers that it is not practicable or effective to suspend concessions or other obligations with respect to the same sector(s), it may seek to suspend concessions or other obligations in other sectors under the same agreement;

(c) if that party considers that it is not practicable or effective to suspend concessions or other obligations with respect to other sectors under the same agreement, and that the circumstances are serious enough, it may seek to suspend concessions or other obligations under another covered agreement;

(d) in applying the above principles, that party shall take into account:

(i) the trade in the sector or under the agreement under which the panel or Appellate Body has found a violation or other nullification or impairment, and the importance of such trade to that party;

(ii) the broader economic elements related to the nullification or impairment and the broader economic consequences of the suspension of concessions or other obligations.

Brazil argued that this provision was inapplicable because the SCM Agreement contained its own provisions for retaliation. The Arbitrator ruled, however, in accordance with the Appellate Body's remarks in Guatemala-Cement, ${ }^{35}$ that special or additional rules such as those in the SCM Agreement do not displace more general rules unless there is a conflict between them. Here, it was possible to

33 European Communities - Regime for the Importation, Sale and Distribution of Bananas, Recourse to Arbitration by the European Communities under Article 22.6 of the DSU, WT/DS27/ARB, 9 April 1999.

34 United States-Measures Affecting the Cross-Border Supply of Gambling and Betting Services, Recourse to Arbitration by the United States under Article 22.6 of the DSU, WT/DS285/ARB, 21 December 2007.

35 Appellate Body Report, Guatemala-Anti-Dumping Investigation Regarding Portland Cement from Mexico, WT/DS60/AB/R, 2 November 1998. 
adhere to both sets of rules, and hence they should be applied together as complementary.

The Arbitrator also ruled that the text requires a fair amount of deference to the complaining nation - the phrase ' if that party considers that it is not practicable or effective' places considerable discretion in the hands of the complaining party, and the Arbitrator must simply ensure that it 'takes into account' the factors in paragraph (d). The United States had the burden of proving that Brazil had not met its obligations, and the Arbitrator could only 'broadly judge' whether Brazil had behaved inappropriately. ${ }^{36}$

Turning to the standards for cross-retaliation under Article 22.3(a)-(c), the question is whether retaliation in the same sector (a) or in other goods sectors (b) is 'practical and effective'. The Arbitrator read 'practical' to refer to the 'actual availability or feasibility' of the retaliation ${ }^{37}$ - for example, is there enough trade in the pertinent sector(s) to exhaust retaliation rights? The term 'effective' relates to the ability of retaliation to induce compliance, although the Arbitrator ruled that a complaining member cannot elect cross-retaliation just because that would be more effective at inducing compliance - the issue is whether retaliation in the same sector or under the same Agreement would be effective. ${ }^{38}$ Such retaliation might tend to be ineffective, however, if it imposed more harm on the complaining nation than on the violator. ${ }^{39}$ Ineffective means something like the retaliation would impose more harm on the sender than the target. Finally, Article 22.3(c) provides that retaliation under another Agreement is acceptable when the circumstances are 'serious enough'. In this regard, the Arbitrator concluded that 'an assessment of whether same-sector or same-agreement suspension is "not practicable or effective" and of whether "the circumstances are serious enough" may legitimately, and indeed should, take into consideration not only the trade to which the suspension would apply, but also the economic consequences arising from the suspension.' ${ }^{40}$

Applying these standards, the Arbitrator noted that Brazilian imports of goods from the United States totaled US\$18.7 billion, ${ }^{41}$ yet its total retaliation rights relating to both prohibited and actionable subsidies for fiscal year 2006 were only on the order of $\$ 300$ million. The question thus arose whether Brazil could identify $\$ 300$ million worth of US goods with respect to which retaliation was 'practical and effective'. The Arbitrator accepted the argument that retaliation on 'capital goods, intermediate goods and other essential inputs' would harm Brazil unduly because many such goods are tailored for particular buyers, and substitute sources

36 Prohibited Subs. Arb., para. 5.430.

37 Ibid., para. 5.455.

38 Ibid., para. 5.460 .

39 Ibid., para. 5.461.

40 Ibid., para. 5.472.

41 Ibid., para. 5.517. 
of supply are not readily available. ${ }^{42}$ It also allowed Brazil to carve out 'important' consumer goods like autos and books, and certain other important categories like medicine and food if the US market share of Brazil's imports exceeded $20 \%$, raising a presumption that substitution from other sources of supply would be difficult. After making these adjustments, the Arbitrator concluded that retaliation in goods sectors could be practical and effective up to an amount of $\$ 410$ million. ${ }^{43}$ Only if Brazil's total retaliation rights exceeded that amount in some future year might it justify retaliation under another Agreement.

In the event that future retaliation rights exceeded this threshold, however, the Arbitrator was prepared to accept that the circumstances were 'serious enough' to permit cross-retaliation. It based this conclusion largely on a finding that the subsidies in question have a large trade distortive impact that gave the United States a 'persisting competitive advantage'. ${ }^{44}$

\section{Legal analysis}

We have little quarrel with the legal analysis of the Arbitrator. The decision to treat the retaliation provisions of the SCM Agreement as complementary to the provisions of the DSU was reasonable and supported by Appellate Body precedent. The interpretation of the terms 'practical' and 'effective' likewise seems reasonable. Finally, we concur that the text of Article 22.3 vests discretion in the complaining member, and that the standard of review by the Arbitrator is appropriately deferential.

The application of these standards to the facts of the case is somewhat more questionable. The great bulk of Brazilian goods imports from the United States fell into Brazil's category of 'capital goods, intermediate goods, and other essential inputs'. The notion that retaliation against any of these goods would impose undue harm on Brazil seems speculative. No doubt in some cases alternative sources of supply would be difficult to obtain, but it is difficult to imagine that to be the case across the board. Likewise, the presumption that alternative sources of supply for consumer goods would be difficult to obtain anytime the US market share of imports exceeded $20 \%$ seems quite arbitrary.

More fundamentally, the implicit premise that retaliation on consumer goods is generally more 'practical' or 'effective' than retaliation on input products seems questionable. There is no apparent reason to suppose that 'effectiveness' would always be greater with consumer goods. As for what is 'practical', perhaps the Arbitrator is implicitly sensitive to the interest-group politics of retaliation, and in effect views politically difficult retaliation (which hurts producer groups) as impractical, while viewing retaliation that mainly harms consumers as more practical as long as the harm is not too great. It is hardly obvious that the concept of 'practical' under the DSU should be interpreted in this fashion.

42 Ibid., para. 5.535.

43 Ibid., para. 5.565.

44 Ibid., para. 5.601. 
The Arbitrator's application of the 'serious enough' standard is also somewhat conclusory. While it is assuredly true that subsidies can distort trading patterns, it is unclear why the violations at issue here are any more 'serious' than a myriad of other violations of WTO law. Unless one is prepared to say that 'serious' circumstances arise anytime 'prohibited' subsidies are in play - a move that the Arbitrator did not make - it would be helpful to have somewhat more guidance on the principles that distinguish 'serious' circumstances from less serious circumstances. We acknowledge, however, that the inherent vagueness of the 'seriousness' standard makes it difficult to lay down tight rules. And, given the appropriately deferential standard of review in assessing Brazil's determination, we cannot say that the Arbitrator's decision was incorrect.

\section{Economic analysis}

One cannot assess the soundness of the Arbitrator's decision in Upland Cotton from an economic perspective without a theory of the objectives that countermeasures are intended to achieve. Unfortunately, no generally accepted theory of their purpose exists, and indeed a lively academic debate exists over the issue. ${ }^{45}$

Roughly speaking, the various theories of countermeasures divide into two camps. The first, which we term the 'compliance' theory, holds that the function of countermeasures is to punish breach of obligations and induce WTO members to bring their behavior back into compliance. The second, which we term the 'efficient-breach' theory, holds that countermeasures seek only to achieve the 'efficient' level of compliance, and thus allow WTO members to deviate from their obligations when the benefits of deviation exceed the costs of deviation to other WTO members ('efficient breach'). Variations on the efficient-breach theme suggest that the goal of countermeasures is to 'compensate' for breach, ${ }^{46}$ to 'rebalance' concessions following breach, ${ }^{47}$ or to provide a 'safety valve' for political pressure that makes trade negotiators more willing to make trade concessions in the first instance. ${ }^{48}$

The debate among these competing theories invokes various considerations. Aspects of the treaty text can be cited on both sides. ${ }^{49}$ Both sides can also point to elements of the dispute-settlement system that are consistent with their position,

45 The most thorough surveys are perhaps those of Lawrence (2003) and Schropp (2009).

46 If countermeasures compensate aggrieved parties for their losses, then they restore those parties' welfare to its level prior to breach - if a violator is willing to pay such 'compensation' and can still remain better off, breach is efficient.

47 Rebalancing is a somewhat vague concept, but it can be understood either as a version of the compensation idea, or as the economic equivalent of 'rescission' in a contractual setting, so that the welfare of the aggrieved party is restored to its level prior to the exchange of concessions in question.

48 The safety-valve story is also a variant of the efficient-breach claim - a safety valve is valuable if the costs of deviation ex post under the safety valve are exceeded by the mutual gains due to the facilitation of a greater number of concessions ex ante.

49 See Jackson (1997); Sykes (2000). 
and inconsistent with the position of their detractors. Proponents of the efficientbreach perspective, for example, emphasize that the general standard for countermeasures under DSU Article 22 requires measures 'equivalent to the level of nullification or impairment', which is interpreted (as in Upland Cotton) to capture the harm done to complaining nations by the violation, and will not ensure retaliation at a level sufficient to produce compliance. Critics of the efficient-breach camp emphasize the fact that countermeasures do not really 'compensate' aggrieved nations very effectively, for example, and question whether the approach to calculating them in practice has any realistic hope of optimizing the breach decision. We make no attempt to settle the debate here, and simply offer a few basic observations from each perspective.

\section{Implications of the 'compliance theory'}

If the goal of countermeasures is to ensure compliance (or, equivalently, to force any deviation from commitments into a renegotiation process), then it is impossible to specify any unique 'optimal value' for countermeasures. Rather, any system of countermeasures that punishes the violator to a degree that wipes out the gains from the violation will suffice - the gains from the violation thus offer a lower bound on retaliation, but there is no necessary upper bound.

This statement requires several caveats. First, countermeasures are not necessarily the only sanction for violations. Violators may suffer damage to reputation that imposes future costs on their ability to negotiate valuable agreements, for example, or they may suffer various informal sanctions relating to trade issues or other aspects of international relations. If so, the countermeasures required to induce compliance are lessened. Second, as the level of countermeasures increases, expenditures on litigation costs in the WTO system will tend to increase, as will the deadweight costs of whatever countermeasures it employs. These costs offer further reasons why it may make sense to limit countermeasures even if the goal of the system were compliance. Third, if legal error is possible, error costs must be factored into the analysis. The possibility of error in favor of the complainant will weigh in favor of weaker countermeasures, while the possibility of error benefiting respondents will weigh in the other direction. Finally, countermeasures are of little utility unless the threat of them is credible. There is no value in setting countermeasures at a level so high that they will not be employed.

Nevertheless, the 'equivalence' standard of Article 22, which focuses on the harm to aggrieved nations caused by the violation rather than the gains to the violator, is a peculiar standard from the compliance perspective. Likewise, none of the standards for countermeasures in prior arbitrations, whether focused on the lost trade volume suffered by aggrieved nations or on the value of the subsidy bestowed by the violator in a prohibited-subsidies case, has any obvious connection to the level of countermeasures that will ensure compliance. The Arbitrator in Upland Cotton acknowledged this problem as we noted earlier, but insisted that authority for stiffer measures was lacking in the treaty text. If the goal of the 
system is to ensure compliance, therefore, its design, at least as interpreted in the decisions to date, is hard to square with that objective.

Accordingly, we will focus most of the remainder of our remarks on the possible implications of the efficient-breach approach to retaliation. Prior to that discussion, however, we briefly consider the issue of retroactive retaliation.

\section{Retroactive retaliation}

As the Arbitrator held in Upland Cotton, and has been the consistent practice in the WTO, countermeasures are allowed only after the 'reasonable period' for compliance has expired and only then until such time as the violation has been cured. Retaliation for violations in the past is impermissible.

From both the compliance and efficient-breach perspectives, this aspect of the system is puzzling. It seemingly allows members to cheat on their obligations with impunity for extended periods of time, weakening compliance with obligations generally, and doing so in a manner that does nothing to limit violations to cases of 'efficient breach'.

Commentators have offered some speculations about the rationale for limiting retaliation in this fashion. For example, perhaps informal sanctions discourage flagrant cheating to a great extent, and many actual disputes may then involve good-faith disagreements about the content of obligations. Because sanctions in the system are costly and because litigation can provide useful clarification of the bargain for all members (a positive externality), it may make sense to allow parties to litigate these good-faith disputes to conclusion without fear of sanctions if they lose, as long as they are willing to bring their behavior into compliance thereafter. ${ }^{50}$ Related, some nations may have limited compliance capacity due to a lack of technical expertise, especially developing countries, and it may not make sense to impose costly sanctions on them for their 'accidental' violations.

The Upland Cotton case itself casts doubt on this rosy account, however, inasmuch as the US programs at issue - particularly the prohibited subsidies - were rather straightforward violations of WTO rules. It is not difficult to think of other cases as well that do not look much like 'good faith disputes'. Thus, although we are not prepared to say definitively that the system should be modified to allow retaliation for violations in the past, especially given the fact that sanctions are costly and create their own deadweight losses, we do worry that the existing dispute-resolution system may unduly encourage temporary cheating.

\section{Implications of the efficient-breach theory in a model of competing exporters}

We now turn to the heart of our economic analysis, which presupposes that the objective of countermeasures is to induce violators to internalize the costs that their violations impose on others. This objective, as noted, comports with the idea 
that retaliation is not intended to ensure compliance in all cases, but merely to ensure that any violations are approximately 'efficient'. Our approach is based on that of Bagwell and Staiger (2002), who view trade agreements as a mechanism for helping nations to internalize terms-of-trade externalities and to achieve 'reciprocity' in their commercial relations. Howse and Staiger (2006) apply this theory in a two-country, two-good framework with tariffs to suggest how retaliation at a level equal to the lost volume of trade valued at original (pre-violation) prices can enable a complaining nation to restore its welfare (approximately) to what it was before the tariff violation. ${ }^{51}$

The idea underlying the Howse and Staiger proposal is that of 'expectation damages', a so-called 'liability rule' familiar from contract law. In the case of domestic contracts, a liability rule that compensates the injured parties for any damages that are suffered as a result of a breach of contract ensures that breach occurs if and only if joint welfare is enhanced by deviation from the contract provisions. Howse and Staiger apply this idea in the trade context by searching for a set of retaliatory measures ('withdrawal of concessions') that leave the injured countries as well off as they would have been, absent the violation of the trade agreement. As they show in the two-country, two-good setting, sometimes this can be accomplished by an increase in tariffs in the injured country that reduces trade volume by an amount equal to the trade opportunities lost as a result of the violation (valued at pre-violation prices).

However, as Beshkar (2010) has pointed out recently, this expectation-damages rule does not have the same efficiency properties in the trade context as it does in the context of domestic contract law. Its efficiency there relies on the availability of cash transfers as a means of compensation. The cash transfers from one private party to another in the case of a contract violation can make the injured party whole without generating excess burden for the party that undertakes the breach. Accordingly, a party will breach if and only if the joint welfare of all parties to the contract is enhanced by that action.

In contrast, cash transfers typically are not available as countermeasures in WTO disputes. ${ }^{52}$ Instead, the injured parties are offered the opportunity to withdraw concessions; that is, to erect barriers or otherwise impede trade by the party that has violated the agreement. This method of compensation is not the same as a cash transfer, because the retaliation mechanism itself generates efficiency loss. Thus, when a party retaliates with a trade barrier, such as that described by Howse and Staiger, that restores the welfare of the complainant to its level absent the violation, the cost to the violator is larger than the benefit to the injured party. A system that utilizes trade barriers to make the injured party whole is thus overly

51 See also Bown and Ruta (2010).

52 A violator is of course free to offer cash as compensation, as has been done by the United States in the Copyright (United States - Section 110(5) of the US Copyright Act, WT/DS160) and Upland Cotton cases. 
conservative relative to a 'first-best' standard of 'efficient' breach, because the excess burden of the distortive retaliatory measure discourages breach in circumstances where joint welfare would be enhanced by a violation of the agreement. Perhaps such conservatism is appropriate if we take the view that violations should be tolerated only when they generate a Pareto welfare improvement for the parties to the agreement and not just an increase in their joint welfare. ${ }^{53}$ In any case, we shall assume the principle - that the 'suspension of concessions or other obligations authorized by the DSB shall be equivalent to the level of the nullification or impairment' - should be interpreted to authorize retaliatory measures that restore the welfare of the injured party to the level that it would have achieved absent the violation.

In what follows, we extend the approach of Howse and Staiger (2006) to a setting that incorporates domestic and export subsidies and competing exporters. We ask whether it justifies any differences in the retaliatory response to violations involving domestic (actionable) subsidies on the one hand, and export (prohibited) subsidies on the other. We also ask whether it supports using lost trade volume as a metric for retaliation, or supports an approach that ties retaliation to the amount of the subsidy. More generally, we develop the implications of the model for the level of countermeasures that will restore the welfare of the injured party, assuming that retaliation is intended to allow efficient breach, using Pareto improvement as the (high) standard for efficiency.

Consider two countries, Brazil and the United States. Both are net exporters of cotton. The cotton market is competitive and all cotton is perfectly substitutable. Let the world price of cotton be $p^{*}\left(x_{\mathrm{u}}, s_{\mathrm{u}}, s\right)$ where $x_{\mathrm{u}}$ is the US export subsidy and $s_{\mathrm{u}}(s)$ is the US (Brazilian) domestic subsidy.

The Brazilian government has a welfare function that includes consumer surplus $(C S)$, producer surplus $(P S)$, and government revenue $(R)$ as components

$$
W=\alpha P S+C S+\gamma R,
$$

where

$$
\alpha \geq 1 \text { and } \gamma \geq 1 \text {. }
$$

We thus assume that producer surplus receives at least as much weight as consumer surplus, a conventional political economy assumption (see, for example, Baldwin, 1987). The weight given to government revenue perhaps reflects the excess burden of taxation.

Let the United States create a dispute by increasing $x_{\mathrm{u}}$ or $s_{\mathrm{u}}$. For simplicity, assume a 'small' change in US policy. The political welfare cost to Brazil is given by

$$
d W=\left(\alpha y-c-\gamma s y^{\prime}\right) d p^{*},
$$

53 Such a principle is questionable, of course, because the opportunity for efficient breach ex post can yield expected Pareto gains to all parties ex ante, or else other terms of the bargain can potentially be adjusted to make all parties better off. 
where $y$ is Brazilian output, $y^{\prime}$ is the slope of the Brazilian supply curve, $c$ is Brazilian consumption, and $d p^{*}$ is the induced change in the world price of cotton (which is negative). The effect on Brazil can thus be decomposed into a loss of producer surplus, a gain in consumer surplus, and a savings in government revenue because the induced reduction in domestic output of cotton lowers the associated domestic subsidy payment. We can think of the welfare effect as a terms-of-trade effect in that the harm to Brazil is transmitted entirely through the reduction in the world price of a good for which Brazil is a net exporter.

This expression suggests several observations. First, the welfare effect on Brazil does not depend on whether the US policy involves a change in the domestic subsidy or in the export subsidy. What matters to Brazil is simply the magnitude of the induced effect on the world price. Second, the overall effect on Brazil depends on the welfare weights given to the different terms in the welfare function. Finally, the welfare effect depends on Brazil's own domestic-support policies $(s)$.

This last point raises some subtle issues. Suppose, for example, that the Brazilian domestic subsidy has been chosen in the context of an 'optimal' internationalsubsidies agreement, which induces members to choose their subsidies to maximize their domestic welfare without regard to international terms-of-trade externalities (they behave 'as if' these externalities are internalized). This assumption is in the spirit of Bagwell and Staiger (2002), who note that a politically optimal trade agreement is one that sets trade policies at levels that neglect their implications for the terms of trade. When thinking about tariffs, it may be reasonable to use the politically optimal tariffs as the starting point for assessing violations. But this approach seems much less realistic where subsidies are concerned. For example, if importing nations were parties to such an agreement, the agreement might encourage exporters to increase their level of subsidies due to the positive terms-of-trade externalities that they impose on importers. Nothing in the WTO system, of course, does anything of the sort, and, indeed, the treatment of subsidies in the WTO system raises some puzzles for the terms-of-trade theory of trade agreements (see Bagwell and Staiger, 2006). Nevertheless, we will begin our analysis with the implications of this assumption.

If the subsidy $s$ has been chosen by Brazil to maximize $W$ ignoring the terms that involve a change in $p^{*}$, then the level of subsidy would be such that

$$
d W /\left.d s\right|_{p^{*}}=\alpha y-\gamma s y^{\prime}-\gamma y=0
$$

i.e., it would expand Brazilian production to the point where the political gain from higher domestic producer prices $(\alpha y)$ matches the marginal revenue cost $\left(\gamma s y^{\prime}+\gamma y\right)$. Substituting this condition into the expression for $d W$, we have

$$
d W=(\gamma y-c) d p^{*} .
$$

Since the Brazilian domestic subsidy ensures that the gain in Brazilian revenue when output falls offsets part of the loss in producer surplus, what remains from a 
worsening of terms of trade in cotton is the benefit to consumers and a portion of the loss in producer surplus. Notice that if $\gamma=1$, this expression is simply the terms-of-trade loss to Brazil due to the induced change in the world price (i.e., it is the excess of Brazilian production over Brazilian consumption, multiplied by the (negative) change in the world price caused by the increased US subsidy).

As another possibility, suppose that the Brazilian subsidy is set noncooperatively to maximize Brazil's welfare, taking into account the adverse effects of such a subsidy on Brazil's terms of trade. The first-order condition for an optimal Brazilian subsidy (including terms-of-trade effects) implies

$$
d W / d s=\alpha y-\gamma s y^{\prime}-\gamma y+\left(\alpha y-c-\gamma s y^{\prime}\right)\left(\partial p^{*} / \partial s\right)=0 .
$$

Substituting this condition into the expression (1) for the change in Brazilian welfare induced by the US violation, we find

$$
d W=\left[\left(\gamma y-\alpha y+\gamma s y^{\prime}\right) /\left(\partial p^{*} / \partial s\right)\right] d p^{*} .
$$

In this case, Brazil suffers harm from the US policy only to the extent that producer surplus carries greater weight in the government's objective than tax revenues and that Brazilian output is not too responsive to the local price. The optimal Brazilian policy sets the domestic subsidy at a level where the harm from a worsening of terms of trade is balanced by a gain in producer surplus that exceeds the revenue cost of the subsidy. The only reason that Brazil can be harmed by the US policy at all in this case is that the Brazilian subsidy does not affect the incentives facing local consumers and therefore does not fully optimize the initial export level before the US violation. ${ }^{54}$

As a final possibility, suppose the Brazilian government does not subsidize its local cotton growers whatsoever; i.e., $s=0$. The formula for the harm to Brazil from the US policy in expression (1) implies in this case that

$$
d W=(\alpha y-c) d p *
$$

If it happens that $\alpha=1$, the welfare loss is again simply the terms-of-trade loss. With $\alpha>1$, the more typical political-economy assumption, the welfare loss exceeds the terms-of-trade loss as conventionally measured when the subsidy is zero. Producers lose and consumers gain from the US subsidy, but the former weighs heavier in the political calculation than it does in a straight welfare calculation that is the basis for measuring terms-of-trade loss.

In general, the harm imposed on Brazil by a US violation of its WTO obligations depends on a number of factors, including the relative weights that the Brazilian government attaches to producer surplus, consumer surplus, and tax revenue, and the extent of Brazilian support for its own cotton industry, be it zero, 'optimal', or

54 If Brazil were to employ an optimal export subsidy instead of an optimal output subsidy, there would be no marginal harm to Brazil from a small change in US policy. 
otherwise. Of course, the harm to Brazil will be less the closer the initial level of cotton production is to what the Brazilian government would deem to be the optimal scale.

Having characterized the welfare loss to Brazil as a result of the change in US subsidy policy, the next question is: What sort of retaliation can restore Brazilian welfare? Suppose that Brazil retaliates by raising its per-unit tariff $t$ on some good that it imports from the United States - say, automobiles. If Brazil raises the border tax it imposes on each imported car by $d t$, the change in its political welfare is given by

$$
d W=\left\{\left[\alpha y_{a}-c_{a}+\gamma t\left(c_{a}{ }^{\prime}-y_{a}{ }^{\prime}\right)\right]\left(1+\partial p_{a}{ }^{*} / \partial t\right)+\gamma\left(c_{a}-y_{a}\right)\right\} d t
$$

The tariff change that compensates Brazil for the loss from the violation in cotton is one that equates the welfare gain from the tariff on automobiles in (2) to the welfare cost of the illegal US subsidy in (1).

The degree of retaliation that restores Brazil's welfare will depend on how the subsidy on cotton and the tariff on automobiles are set initially. Suppose first that both have been set in the context of a Bagwell-Staiger 'optimal' trade agreement that has induced Brazil to internalize the externalities from its policy choices. Then, as we showed earlier, the welfare loss to Brazil from the US subsidy is simply the political-economy-weighted terms-of-trade loss, $d W=(\gamma y-c)\left(\partial p^{*} / \partial x_{\mathrm{u}}\right) d x_{u}$. If the tariff on automobiles was also set to maximize Brazilian political welfare, but ignoring terms-of-trade effects, it satisfies the first-order condition

$$
\alpha y_{a}-c_{a}+\gamma t\left(c_{a}{ }^{\prime}-y_{a}{ }^{\prime}\right)+\gamma\left(c_{a}-y_{a}\right)=0,
$$

where the subscript $a$ denotes a variable in the automobile industry. Now substituting this condition into the above expression (2) for the welfare change, we find the gain to Brazil from a change in its automobile tariff beginning at the Bagwell-Staiger political optimum, which is

$$
\begin{aligned}
d W & =\left\{\left[\alpha y_{a}-c_{a}+\gamma t\left(c_{a}{ }^{\prime}-y_{a}{ }^{\prime}\right)\right]\left(\partial p_{a}{ }^{*} / \partial t\right)\right\} d t \\
& =-\gamma\left(c_{a}-y_{a}\right)\left(\partial p_{a}{ }^{*} / \partial t\right) d t .
\end{aligned}
$$

The term on the right-hand side corresponds to the weighted gain in tariff revenue on the initial volume of imports. This is the marginal gain to Brazil from increasing its tariff, considering that the initial tariff was set to optimize the political outcome, but neglected the implications for the terms of trade.

Finally, if we equate the gain from the retaliatory tariff increase on automobiles to the loss suffered by Brazil as a result of the US violation, we have

$$
(\gamma y-c)\left(\partial p^{*} / \partial x_{u}\right) d x_{u}=\gamma\left(c_{a}-y_{a}\right)\left(\partial p_{a} * / \partial t\right) d t
$$

A sufficient condition for the tariff change to be positive $(d t>0)$ in this expression is that $\gamma \geqslant 1$. Then, Brazil's welfare will be restored by an increase in the tariff on autos that offsets the terms-of-trade loss on cotton. To calculate the appropriate 
value of $d t$, however, one must know the relative welfare weight attached to government revenue relative to consumer surplus.

If the welfare weight that Brazil attaches to government revenue is the same as that on consumer surplus $(\gamma=1)$, then (3) mandates a retaliatory tariff that generates a terms-of-trade improvement on automobile imports that exactly matches the terms-of-trade loss suffered by Brazil on its cotton exports, both measured in the conventional way; i.e., as the initial volume of trade multiplied by the change in the border price. As Lawrence (2003) and Bagwell (2008) have aptly noted, however, this result rests on the assumption that the US violation is a small one. A larger violation will cause Brazilian cotton exports to fall significantly short of the level dictated by the political optimum, and the retaliatory tariff will similarly generate a sub-optimally low level of automobile trade. Thus, in general, the tariff that induces a terms-of-trade gain for Brazil in automobiles just equal to its terms-of-trade loss in cotton will not suffice to restore Brazil's welfare to its initial, pre-violation level.

Things become considerably more complicated if the cotton subsidy and auto tariff are not initially set at their 'politically optimal' values. Then we must use the general expression for the welfare effects of a tariff change (given above in (2)), which requires information not only on the relative weight on revenues compared to consumer surplus, but also on the political-economy weight for producer surplus. The former may be approximated by the excess burden of taxation - for which estimates are available for many countries - but the latter is much more difficult for the Arbitrator to assess.

In sum, although there exists a change in the auto tariff that restores Brazil's welfare, the task of calculating it is a difficult one. It requires assumptions about the relevant political-economy weights on different components of Brazilian welfare, as well as assumptions about how the initial values of Brazil's policy instruments have been determined.

But we can identify a simple benchmark case that arises when politicaleconomy weights in Brazil are the same for producer surplus, consumer surplus, and government revenue, and the Brazilian cotton subsidy is zero. On the assumption that all components of welfare receive equal weight, the politically optimal level of subsidy is zero (because the politically optimal subsidy ignores terms-of-trade considerations, and with a national income maximizing government, there is no reason to subsidize for purposes of domestic redistribution). Then, with an initial subsidy of zero, we can use our earlier result for the case where the subsidy level is politically optimal to conclude that Brazil's welfare will be restored by retaliation in the import industry that exactly offsets the terms-of-trade loss - the resulting change in the world price of the import good, multiplied by the initial volume of Brazilian imports, should match the change in world price of cotton induced by the violation multiplied by the initial volume of Brazilian cotton exports. Once again, this proposition is subject to the caveat that for a 'large' breach, this level of retaliation will fall somewhat short of restoring lost welfare. 
Furthermore, although the point may seem obvious from the mathematics, we think it worth underscoring that the approach here suggests a level of retaliation that restores the level of welfare for Brazil, not for the world as a whole. It is thus broadly consistent with the approach of the Arbitrator in Upland Cotton (and contrary to the approach in the FSC case), in that proper countermeasures depend on the harm suffered by the complaining Member. ${ }^{55}$

We conclude with a comment and extension on some prior work, which has suggested that appropriate retaliation can be approximated by equating the 'trade volume' effects of the retaliatory measure with those of the initial violation. This observation is particularly significant inasmuch as it comports with the way that some Arbitrators have calculated permissible retaliation.

Howse and Staiger (2006) and Bown and Ruta (2010) consider the consequences of a violation that reduces a country's exports of some good, call it good 1 . They suggest that a retaliatory tariff on, say, good 2, which reduces the value of good 2 imports by an amount equal to the value of lost exports of good 1 valued at the original (pre-violation) prices, will restore the welfare of the aggrieved exporter. In other words, they suggest that the appropriate terms-of-trade changes needed to compensate an injured party can be achieved in some circumstances by focusing on trade-volume (value) effects, rather than on terms-of-trade (price) effects per se. They develop this claim in a model with only two goods and two countries, and we now ask whether it is valid in a more general setting.

Let us continue to suppose that the United States and Brazil export cotton to the rest of the world and that Brazil imports automobiles from the United States. Brazil retaliates for a US violation in cotton by raising its import tariff on automobiles. Besides these two goods, there are others that are traded, so that changes in Brazil's exports of cotton need not be balanced by changes in its imports of automobiles. We examine a tariff increase for Brazil that restores its welfare to the level before the US violation and ask under what conditions this policy change also implies a decline in the value of automobile imports that matches the decline in the value of Brazilian exports of cotton.

To keep the analysis simple, let us now assume that the Brazilian government is a national-welfare maximizer in the traditional sense - all components of welfare receive equal weight $(\alpha=\gamma=1)$. Let the retaliatory tariff be set so that the gain to Brazil from the fall in the (world) price of autos just offsets the loss of welfare due to the fall in the world price of cotton. Condition (4) captures this requirement

$$
(y-c) d p^{*}=\left(c_{a}-y_{a}\right) d p_{a}{ }^{*}
$$

55 We must acknowledge, however, that if the goal is to facilitate efficient breach and discourage inefficient breach, it is important that the welfare effects of a violation on all WTO Members be internalized by the potential violator. To the degree that some injured nations lack the resources to bring complaints or lack retaliatory capacity (notwithstanding the possibility of cross-retaliation), the price for breach can become too small. 
We ask now what are the trade effects induced by the US subsidy and the retaliatory tariff that satisfy (4).

Standard supply-and-demand analysis can be used to link the change in the world price of cotton to the change in the US subsidy. The price change induced by a given subsidy will depend on the export-supply elasticities in Brazil and the United States and the import-demand elasticity in the rest of the world. Similar analysis can be used to link the change in the price of US automobiles to the change in the Brazilian tariff; this will reflect the export-supply elasticity in the United States and the import-demand elasticity in Brazil. Finally, we require that the terms-of-trade effects are compensatory; i.e., the Brazilian tariff is set in response to the US subsidy to ensure that condition (4) is satisfied. In this way, we can calculate the effect of the US subsidy on Brazilian exports of cotton and the effects of the retaliatory tariff on its imports of automobiles, and we can check when these trade effects will match.

We find that the trade effects of the compensatory tariff match those of the US cotton subsidy if and only if the US elasticity of export supply for automobiles is equal to the elasticity of Brazilian export supply for cotton. Put differently, a retaliatory tariff that equates the trade-volume effects valued at the original prices will restore Brazil's welfare if and only if the supply of US automobile exports responds to a percentage change in the US price of autos by the same percentage amount as Brazilian cotton exports respond to a percentage change in the Brazilian price of cotton. Of course, there is no reason that this should be the case, especially if the sector for retaliation (in this example, 'automobiles') is chosen somewhat arbitrarily. We conclude that the approach to retaliation that balances trade effects is not likely to achieve its ostensible purpose in a world with more than two countries, more than two goods, and an arbitrary sector in which the retaliatory measure is applied.

It should also be noted that the trade-effects remedies applied by previous Arbitrators differ in an important way even from those proposed by Howse and Staiger (2006) or Bown and Ruta (2010). These commentators have provided limited justification (subject to the strong caveat discussed above) for retaliatory tariffs that reduce the volume of trade by an amount equal to the trade lost by the complainant as a result of the violation, but that nonetheless leave imports at a positive level. The idea behind retaliation in their framework is that the complainant should be able to import more cheaply so that its terms of trade improve. But an improvement in terms of trade requires that there be positive trade after the tariff hike. In contrast, Arbitrators in the past have simply calculated a total amount of trade that may be the subject of retaliation. The subsequent retaliation has then often taken the form of probibitive tariffs on a volume of trade equal to the trade lost by the complainant in the industry where the violation occurred. A prohibitive tariff cannot induce an improvement in the terms of trade, and therefore it cannot be used 
to restore the complainant's welfare to what it would have been absent the violation. ${ }^{56}$

Perhaps the reason that prohibitive tariffs have been popular in the past is that they are relatively easy to apply. Once the Arbitrator calculates how much trade has been lost due to the violation, there is no further information about the supplyand-demand conditions in the industry of retaliation that is needed to ensure an equal trade-volume effect when prohibitive tariffs are used. But prohibitive tariffs will generally reduce welfare in the complainant country, and so are an odd instrument of retaliation given that alternative, nonprohibitive tariffs could impose the same harm on the violator while generating a gain for the complainant. ${ }^{57}$

Our analysis suggests that a more rational approach to retaliation would employ nonprohibitive tariffs that enhance the terms of trade. But the application of the equal-trade-effects principle with nonprohibitive tariffs requires information about supply-and-demand elasticities in the retaliation industry in order to calculate the requisite tariff hike. But then, as we have also argued, there will be no guarantee that the implied tariffs will restore welfare to something close to what it would have been absent the violation.

Note, however, that once the Arbitrator has information about supply-anddemand elasticities in the industry where retaliation will take place, there is no need to use the equal-trade-effects approach to approximate proper retaliation. The Arbitrator could instead directly calculate the tariff that would generate a terms-of-trade gain in the retaliation industry equal to the loss in the violation industry, using the same information necessary to calculate the tariff that would generate equal trade effects in the two sectors. The tariff that induces a terms-oftrade gain equal to the loss suffered due to the violation is likely to be closer to the one that ensures efficient levels of breach than the one that induces an equal trade effect for the reasons given above. We conclude that Arbitrators ought to devote more attention to the terms-of-trade implications of retaliation, and less to the effects of retaliation on the volume of trade than has been true in the recent past.

\section{Other issues: cross-retaliation, elasticities}

\section{Cross-retaliation}

We will not attempt to model the implications of cross-retaliation under GATS or TRIPS, which raises a range of issues that range beyond our simple modeling

56 Put more precisely, a prohibitive tariff on some good can only generate a terms-of-trade improvement for the importing country if it results in a reduced price of imports of some other good, or an increased price of exports of some other good. But this would require a particular pattern of substitution between the good with the prohibitive tariff and other imports and exports, and there is no reason to believe that the prohibitive tariff with equal trade effects would improve terms of trade in other sectors by just the right amount to compensate both the loss of welfare due to the violation plus the loss of welfare associated with the cessation of imports in the industry subject to retaliation.

57 Of course, prohibitive tariffs can, in principle, cause the violator to suffer harm equal to the harm suffered by other WTO Members. In this sense, they can confront the violator with a penalty that leads to efficient breach in the Kaldor-Hicks sense. 
framework. Instead, we offer a few informal thoughts on the wisdom of allowing complaining nations to choose either the industry or sector in which to retaliate.

Consider first a case involving a violation of the rules with respect to trade in goods (like Upland Cotton). Under WTO practice, the complaining nation will have considerable flexibility to choose the goods industry or industries in which to exercise retaliation rights. Is this desirable? Intuitively, the modeling framework here suggests that retaliation should come in the industry where the (politically weighted) terms-of-trade gain to the retaliator (which is what compensates the injured party) comes at the least deadweight loss. If the initial tariff rates before retaliation are all politically optimal in the sense of Bagwell and Staiger, then there is no deadweight loss from a small change in any tariff, and it does not matter which tariff (or tariffs) is chosen for retaliation. It matters only that the total magnitude of retaliation (and the attendant terms-of-trade gain) is appropriately calibrated.

If the initial tariffs are not politically optimal, then the details of the retaliation that restores the complaining nation's welfare will affect the amount of collateral deadweight loss. If the rule for retaliation does NOT take this fact into account (which is the case in practice), then the retaliator will, given the choice, tend to choose the industry where the retaliation does the least harm to itself. This observation affords one reason in favor of letting the retaliator choose the industry in which to retaliate. But of course the retaliatory option that is optimal for the retaliator may not be optimal from a global perspective, and an argument might be made for channeling retaliation into the instruments that cause the smallest global loss. As a practical matter, however, it is difficult to imagine how Arbitrators could accomplish this task.

What about retaliation under other WTO Agreements ('cross-retaliation' in WTO parlance)? In past arbitrations, the goal of complaining nations seeking cross-retaliation rights, of course, has been an authorization to retaliate under TRIPs. Such retaliation involves a host of issues that go beyond conventional trade models. On the one hand, for example, TRIPs retaliation might adversely affect incentives for innovation and be relatively unattractive for that reason. On the other hand, perhaps TRIPs retaliation might have little effect on incentives and primarily amount to a transfer of rents from interest groups in the violator country to the complaining nation. If so, it may have the nice property that it is much closer to a 'transfer' than traditional trade sanctions, which may make it relatively attractive. Indeed, if TRIPs retaliation could be orchestrated in such a way as to avoid damaging innovation incentives (or other valuable interests served by intellectual property rights), and could be made to resemble pure transfers as a first approximation, then it might dominate trade sanctions quite broadly.

Finally, and as others have recognized, cross-retaliation empowers nations with little capacity to retaliate under GATT or GATS with some prospect of meaningful and credible sanctions. To this extent as well, it has potential merit. 


\section{Long-run versus short-run elasticities}

Consider a violation of WTO rules that will remain in place for an extended period of time-perhaps, for example, it is an 'efficient breach'. The harm from the violation over time will be the present discounted value of a sequence of annual harms. Initially, the harm will tend to be greater because resources in the industries harmed by the violation have not been able to redeploy themselves to opportunities that may earn higher returns. In time, the harm will decline as resources are reallocated and sunk capital depreciates.

The first-year's harm is best calculated with short-run elasticities, the second year with somewhat longer-run elasticities, and so on. Thus, if an Arbitrator is calculating the allowable retaliation for the near term only, short-run elasticities may be appropriate (although one must ask how long the violation has been in place, and whether a lot of adjustment may already be underway). If the Arbitrator wishes to establish a formula for retaliation that will apply for many years to come, by contrast, it is inappropriate to rely solely on short-run elasticities.

The more general point is that the harm caused by a violation is time variable, and will typically decrease over time as affected industries adjust and reallocate resources elsewhere. The Arbitrator's formula in Upland Cotton was apparently intended to govern retaliation for a period of years, and indeed has been applied on an ongoing basis. One might argue that if the goal is to afford compensatory retaliation to Brazil over time, the formula should have included some mechanism for adjusting downward the estimate of harm to Brazil over time, holding constant the value of the underlying subsidies. To be sure, the precise adjustment required would be difficult to specify.

\section{Summary}

Economic analysis can say little about 'optimal' retaliation in the WTO system, absent a theory of what retaliation is supposed to accomplish. If the goal is 'ensuring compliance', then the focus ought be on guaranteeing that violators cannot profit from their violations, a focus that is at odds with the treaty text as presently interpreted. If the goal is 'efficient compliance' (and its corollary 'efficient breach'), then the emphasis should be on 'compensating' WTO members harmed by a violation through countermeasures that restore their lost welfare.

The fact that WTO members can 'cheat' for an extended period of time without suffering any formal sanction raises a puzzle under either perspective. Perhaps the system can be explained by a desire to minimize the use of costly sanctions, by the role of informal sanctions that discourage flagrant cheating, and by the positive externalities associated with formal litigation to clarify the bargain (which might be discouraged by stiffer sanctions), but these explanations are at best speculative.

Putting this puzzle to the side, the 'equivalence' standard for countermeasures under DSU Article 22.4, and the determination by the Arbitrator in Upland Cotton that sanctions should be linked to harm suffered by Brazil, all point to a system that is focused more on rebalancing the bargain and at least crudely on restoring 
the welfare losses caused by the violation than on ensuring 'compliance'. Accordingly, we have focused our economic analysis on the task of identifying the level of retaliation that will restore lost welfare.

This is not an easy task. Although we can derive expressions for the proper level of retaliation, they depend on the welfare weights that each nation gives to various components of welfare, which are unobservable. The welfare implications of retaliation through changes in trade-policy instruments also depend importantly on how those policies have been chosen in the first instance. It is thus unrealistic to expect that WTO arbitrators can do a good job at identifying the retaliatory measures that will restore lost welfare with much accuracy.

Under certain quite restrictive assumptions, however, the analysis provides some support for an approach to retaliation that allows the retaliator to reduce the value of its imports by an amount equal to the value of its lost exports due to the violation. We extend the result in Howse and Staiger (2006), in particular, to show that this approach can approximately restore lost welfare if one is willing to assume that all components of welfare receive equal weight, and that trade in other goods is not affected significantly following the violation and the subsequent countermeasure. Although these assumptions are probably unrealistic in general, our analysis provides at least weak support for the trade-volume-effects calculation in past arbitrations.

The use of prohibitive tariffs for purposes of retaliation is more puzzling, as they cannot in general restore lost welfare for the complainant - nonprohibitive tariffs that enhance the terms of trade seem to make more sense. To this end, our analysis suggests that the same information required to compute the nonprohibitive tariffs that will produce an equal trade-volume effect could instead be used to compute the tariffs that would offset the terms-of-trade loss due to the violation. Such an approach seemingly holds more promise as a way to approximate the level of retaliation that would restore the welfare of the complainant.

Finally, nothing in our analysis provides any support for the measure of retaliation used in prohibited-subsidies cases prior to Upland Cotton which has been the amount of the subsidy. Likewise, our analysis suggests no reason why the approach to retaliation should differ in subsidies cases generally, or in prohibitedsubsidies cases in particular. Perhaps there is some basis for treating the 'prohibited subsidies' as a more pernicious practice subject to greater condemnation, but if the concern is for their effect on the welfare of other nations, it is the magnitude of the terms-of-trade effect that matters and not the formal structure of the subsidy program.

\section{References}

Bagwell, Kyle (2008), 'Remedies in the WTO: An Economic Perspective', in Merit E. Janow, Victoria J. Donaldson, and Alan Yanovich (eds.), The WTO: Governance, Dispute Settlement and Developing Countries, Huntington, NY: Juris Publishing, pp. 733-770. 
Bagwell, Kyle and Robert W. Staiger (2002), The Economics of the World Trading System, Cambridge, MA: MIT Press.

— (2006), 'Will International Rules on Subsidies Disrupt the World Trading System?', The American Economic Review, 96(3): 877-895.

Baldwin, Richard E. (1987), 'Politically Realistic Objective Functions and Trade Policy: PROFS and Tariffs', Economics Letters, 24(3): 287-290.

Beshkar, Mostafa (2010), 'Optimal Remedies in International Trade Agreements', European Economic Review, 54(3): 455-466.

Bown, Chad P. and Michele Ruta (2010), 'The Economics of Permissible WTO Retaliation', in Chad P. Bown and Joost Pauwelyn (eds.), The Law, Economics and Politics of Retaliation in WTO Dispute Settlement, Cambridge: Cambridge University Press, pp. 149-193.

Howse, Robert and Damien J. Neven (2005), "United States - Tax Treatment for "Foreign Sales Corporations", Recourse to Arbitration by the United States under Article 22.6 of the DSU and Article 4.11 of the SCM Agreement (WT/DS108/ARB), A Comment', in Henrik Horn and Petros C. Mavroidis (eds.), The WTO Case Law of 2002: The American Law Institute Reporters' Studies, Cambridge: Cambridge University Press, pp. 36-63.

Howse, Robert and Robert W. Staiger (2006), 'United States - Anti-Dumping Act of 1916 (Original Complaint by the European Communities) - Recourse to Arbitration by the United States under 22.6 of the DSU, WT/DS136/ARB, 24 February 2004: A Legal and Economic Analysis', in Henrik Horn and Petros C. Mavroidis (eds.), The WTO Case Law of 2003: The American Law Institute Reporters' Studies, Cambridge: Cambridge University Press, pp. 254-279.

Jackson, John H. (1997), 'The WTO Dispute Settlement Understanding-Misunderstanding on the Nature of Legal Obligation', American Journal of International Law, 91(1): 60-64.

Lawrence, Robert Z. (2003), Crimes and Punishments? Retaliation Under the WTO, Washington, DC: Peterson Institute for International Economics.

Schnepf, Randy (2010), Brazil's WTO Case Against the US Cotton Program, Washington, DC: Congressional Research Service.

Schropp, Simon A. B. (2009), Trade Policy Flexibility and Enforcement in the WTO: A Law and Economics Analysis, Cambridge: Cambridge University Press.

Schwartz, Warren F. and Alan O. Sykes (2002), 'The Economic Structure of Renegotiation and Dispute Resolution in the World Trade Organization', The Journal of Legal Studies, 31(1): S179-S204.

Sykes, Alan O. (2000), 'The Remedy for Breach of Obligations under the WTO Dispute Settlement Understanding: Damages or Specific Performance?', in Marco Bronckers and Reinhard Quick (eds.), New Directions in International Economic Law: Essays in Honour of John H. Jackson, The Hague: Kluwer, pp. 347-357. 